\title{
Political Discourse, Code-Switching, and Ideology
}

\author{
Stephanie Moody ${ }^{1}$ and Zohreh R. Eslami, \\ 1 Texas A\&M University \\ College Station, USA \\ 2 Texas A\&M University-Qatar \\ Doha, Qatar
}

\begin{abstract}
Language and Ideology is an area of critical discourse analysis that has increasingly gained importance in the linguistic sciences. The vast influence of the media has provided a need for the explicit analysis of common linguistic mechanisms, particularly those in political discourse. Codeswitching, general pattern in a speech community of switching between two or more available languages or dialects with respect to certain extralinguistic factors (Blom \& Gumperz 1972) is strategically employed by politicians to gain support for elections (Jarraya 2013; Craig 2013). Senator Tim Kaine was one of the first White politicians to engage in code-switching during the 2016 presidential election, however his use of Spanish when engaging in political discourse was met with great resistance and skepticism by the media and voters, many of whom felt that he was pandering to Spanish-speaking citizens. Using a language ideologies framework, the present paper seeks to determine how code-switching was used as a political discourse device by Senator Kaine, and how its use varied based on the context of each speech. To answer these questions, four speeches given by Senator Tim Kaine during the 2016 presidential campaign were transcribed and translated. Following descriptive coding procedures by Saldaña (2015), two raters coded instances of codeswitching in each speech for key features of political discourse: a) dissemination of personal information or background; b) repetition; c) hyperbole; d) metaphor; e) metonymy; f) comparisons; g) promises for the future; h) solidarity; i) legitimization of self as authority; and j) florid verbiage. Results show that Senator Kaine relied most heavily on code-switching during his speech in Miami, Florida, and used it as a tactic to gain support and build solidarity between himself and members of the audience. Additionally, Senator Kaine engaged in much repetition through code-switching to emphasize key points of his speech and political goals. The present study illustrates how codeswitching can be used to cultivate political favor, forge alliances, and demonstrate cultural similarities between White politicians and bi- and multilingual voters.
\end{abstract}

Keywords: bilingualism, code-switching, political discourse, critical discourse-analysis

\section{For citation:}

Moody, Stephanie and Zohreh R. Eslami. 2020. Political discourse, code-switching, and ideology. Russian Journal of Linguistics 24 (2). 325-343. DOI: 10.22363/2687-0088-202024-2-325-343 
Научная статья

\title{
Политический дискурс, переключение кода и идеология
}

\author{
Стефани Муди ${ }^{1}$, Зохрэ Р. Еслами ${ }^{1,2}$ \\ ${ }^{1}$ Техасский университет А \& M \\ Колледж-Стейшен, США \\ ${ }^{2}$ Техасский университет А \& М в Катаре \\ Доха, Катар
}

\begin{abstract}
Аннотация
Язык и идеология - это область критического дискурс-анализа, которая привлекает все большее внимание лингвистов. Возрастание влияния средств массовой информации обусловило необходимость анализа языковых механизмов, особенно в политическом дискурсе. Переключение кода между двумя и более языками или диалектами в соответствии с определенными экстралингвистическими факторами (Blom \& Gumperz 1972) является стратегией политиков, используемой для получения поддержки на выборах (Jarraya 2013; Craig 2013). Сенатор Тим Кейн был одним из первых белых политиков, применивших переключение кода во время президентских выборов 2016 года. Однако использование им испанского языка в политических выступлениях вызвало неодобрением и скептицизмом у средств массовой информации и избирателей, многие из которых посчитали, что он заигрывает перед испаноязычным населением. Цель данной статьи - определить, как переключение кода использовалось сенатором Кейном в качестве инструмента политического дискурса и как оно варьировало в зависимости от контекста каждого выступления. Чтобы ответить на эти вопросы, мы проанализировали четыре речи сенатора Кейна во время президентской кампании 2016 года, которые были предварительно застенографированы и переведены. Применяя метод описательного кодирования (Saldaña 2015), два эксперта выделили случаи переключения кода в каждой речи для выделения ключевых характеристик политического дискурса: a) распространение личной информации или фактов жизни; б) повторы; в) гипербола; г) метафора; д) метонимия; е) сравнения; ж) обещания на будущее; з) солидарность; и) легитимация себя как власти; к) витиеватое многословие. Результаты показали, что сенатор Кейн больше всего полагался на переключение кода и использовал его в качестве тактики, чтобы заручиться поддержкой аудитории и выстроить доверительные с ней отношения, во время своего выступления в Майами, штате Флорида. Кроме того, через переключение кода сенатор Кейн многократно делал повторы, чтобы выделить ключевые моменты своей речи и свои политические цели. Проведенное исследование показало, как переключение кода может использоваться в целях получения политического преимущества, создания альянсов и демонстрации культурных сходств между белыми политиками и дву- и многоязычными избирателями.
\end{abstract}

Ключевые слова: билингвизм, переключение кода, политический дискурс, критический дискурс-анализ

\section{Для цитирования:}

Moody, Stephanie and Zohreh R. Eslami. 2020. Political discourse, code-switching, and ideology. Russian Journal of Linguistics 24 (2). 325-343. DOI: 10.22363/2687-0088-2020-242-325-343 


\section{Introduction}

"I'm grateful to you, Hillary, for the trust that you place in me. And we're going to be compañeros de alma in this great lucha ahead."

Senator Tim Kaine, from his speech in Miami, FL on July 23, 2016.

The above quote is from Senator Tim Kaine, a Democratic candidate in the 2016 United States (U.S.) presidential race who became well known for his use of code-switching on the campaign trail. Code-switching is a natural practice for biand multilingual individuals, and its use in political campaigns is becoming increasingly common across the world (Opeibi 2007). Despite this, most research on code-switching in the U.S. has focused on dialectical shifts, such as Barack Obama's use of "African American English" (AAE) and "standard English" (SE), and has not sought to understand politician's code-switching between different named language systems (e.g., Young 2009). We contend that no text is neutral, including that which involves code-switching; politicians make use of certain rhetorical and discourse strategies in their political discourse to persuade voters to subscribe to their viewpoint (see Weiss \& Wodak 2003). Political speech, in particular, is strategically planned to be convincing, to appeal to the emotions of voters, to portray a particular political persona (Corner 2003), and to "construct alliances and membership" (Wodak 2004). The current study presents an attempt to investigate the use of code-switching by Senator Kaine as one type of persuasive rhetorical-discursive device during his campaign for presidency in 2016. Specifically, the following questions will be answered: 1) How did the amount and length of Senator Kaine's use of code-switching vary across the four analyzed speeches? and 2) How did Senator Kaine use code-switching as a persuasive rhetorical-discursive device?

To answer these questions, we must first understand the standard characteristics of political discourse and code-switching as an important verbal strategy in political discourse with which one can achieve pragmatic and strategic functions without assuming the responsibility or the risk of being put on record (Obeng 1997). Previous studies related to code-switching in political discourse will be reviewed for their contribution to our understanding of how politicians around the world use multiple languages, dialects, and codes to meet their political agendas.

\section{Political Discourse}

Political discourse is inherently different from other types of discourse (Hay 2013 ) in that the promotion of individual and party interests is valued over everything else, and therefore calculated deceit is a routine practice (Corner 2003). Since a politician's main goal when speaking is to persuade the audience to their position, they are naturally attuned to every verbal nuance in their discourse (e.g., Davletbaeva, Yashina \& Sharafieva 2016; Mirzaei, Eslami, \& Safari, 2017; Ponton, 
2016; Quam, \& Ryshina-Pankova, 2016). Politicians try to make their speech clear and comprehensible for all members of the audience so that the agenda they are promoting is easily understood (Davletbaeva et al. 2016); this includes developing compelling and convincing arguments. These general goals mean that all political speech shares some similar characteristics, regardless of the country the politicians represent or the language it is delivered in.

Language is what creates politics; political activities are nonexistent without the systematic manipulation of language to formulate and perpetrate a specific political agenda (Chilton 2004). Politicians use language to create intimacy with their constituents by demonstrating their personal and emotional commonalities, so that the audience will feel that they are members of the same 'group' as the political leader (Reyes 2015). At the same time, they must show their expertise and authority in order to validate themselves as political leaders (Chilton 2004). To accomplish this, all political discourse includes certain features and structures. Examples of these are the sharing of personal information, repetition and anaphora, exaggeration, figurative language, comparisons between countries and political parties (Davletbaeva et al. 2016), persuasion, shallow promises, boasting about performance, positive self-presentation, analogies (Chilton 2004), use of the plural 'we', and horror stories about political opponents (van Dijk 1997).

Political discourse is a site of struggle for various power groups that engage in a race to gain public support at the cost of smearing their opponents. Political elites resort to various discourse structures, strategies, and rhetorical moves to present their ideologies and stand against other powerful groups (van Dijk 2006b). The present study seeks to understand the ideological loading and discursive strategies in this genre, and is driven by an understanding that political discourse is inherently ideological and an opportunity for politicians to gain public approval and status by denigrating those that stand in opposition. Our framework is focused on discovering the strategies and structures employed in the discourse of politicians to challenge their opposing party. For this purpose, the framework of critical discourse analysis (e.g., Chilton 2004; Fairclough 1995; van Dijk 1997; Weiss \& Wodak 2003) is considered suitable for uncovering agendas and strategies (e.g., code-switching) of the politicians in the light of the concepts of power and dominance. We demonstrate that code-switching in political discourse is an interpersonal strategy that can be used to create, strengthen or destroy interpersonal boundaries, and thus it functions as a discourse strategy for pragmatic and strategic purposes (Wei 2003).

While language use in political campaigns, interviews, and speeches has been widely researched, few studies have examined how these discourse features are used by bi- and multilingual politicians in the United States. In the following section we will review the existing research related to the fluid use of languages within political discourse. 


\section{Code-Switching in Political Discourse}

The application of two or more languages within a single interaction is often called code-switching, and constitutes an alternation between two or more languages within the same sentence or conversation (Scotton \& Ury 1977). Speakers often switch for just one word, an entire sentence, or even for longer monologues (Scotton \& Ury 1977). Code-switching can be both conscious and unconscious on the part of the speaker, but it is related to the role that the speaker wants to portray within a conversation; thus, a code-switch is indicative of a change in roles on the part of the speaker (Scotton \& Ury 1977). In the U.S., many presidents have engaged in code-switching, most recently Bill Clinton's use of German and English during a speech at Brandenburg Gate, George W. Bush's consistent integration of Spanish, and Barack Obama's exchange of greetings and pleasantries in Indonesia (see "List of Multilingual Presidents in the United States" n.d.). These examples of code-switching represent a tradition of its use by presidents as a consensus-building strategy, however to our knowledge no research has focused on examining how often, in which context and for what functions it is used in political speech in the United States. A variety of research has been conducted on code-switching in political discourse in other countries, which will be discussed below.

Kementchedjhieva (2016) analyzed the discourse of the Prime Minister of Bulgaria for his code-switching tendencies and determined that he varied his speech differently depending on the context of the situation; he used more non-standard speech patterns when participating in non-mediated interactions (such as casual conversations) with common citizens, however when participating in mediated interactions (those adhering to standard interview protocol) he combined both standard and non-standard forms of interaction (Kementchedjhieva 2016). Kementchedjhieva believed this to be due to the Prime Minister's desire to seem authoritative while also portraying an image of a 'regular guy' who can connect with common people. Similarly, Uzum and Uzum (2010) studied how Turkish politicians borrowed words from a variety of languages in their campaign speeches. They examined what types of words were borrowed (nouns, verbs, etc.), the position of the word in the sentence, the context of its use, frequency, stress, and phonological variation of each word (Uzum \& Uzum 2010). Their analysis revealed that borrowed words constituted $42 \%$ of the dialogue of Turkish politicians during speeches; nouns were borrowed the most frequently, were emphasized more heavily than Turkish words, and were most often used in the middle of sentences (Uzum \& Uzum 2010). Swahili and English code-switching and storytelling in Tanzanian campaign speeches was analyzed by Bwenge (2009); he found that ethnic roots, membership to a certain group or culture, and personal educational attainment were all interplayed within the discourse of Tanzanian politicians. Opeibi (2007) examined how Nigerian politicians used code-switching and code-mixing in political adverts as a campaign strategy. Analysis of campaign ads from Nigerian 
newspapers showed that code-switching was employed to create solidarity, express emotions, convey meaning, and break ethnic barriers (Opeibi 2007).

The abovementioned studies have two things in common: they involve politicians from countries outside of the United States, and they analyze political speeches and text through a code-switching lens.

\section{The U.S. Context}

There are currently 58.9 million Latinx people living in the U.S. (U.S. Census Bureau 2018), approximately 4.9 million of which are undocumented immigrants from Mexico (Pew Research Center 2019). These individuals make up one-third of the foreign born population, a number that is far greater than that of any other nationality group (McCann \& Chávez 2016). Unfortunately, there has been a long history of discrimination against Mexican immigrants in the U.S., which extends to individuals who are U.S. citizens but contain Mexican ancestry (Johnson \& Trujillo 2011). This has been compounded in recent years by politicians like Donald Trump, a Republican, who has targeted Mexican immigrants as "criminals" and "rapists" and has continually threatened to build a wall between the border of Mexico and the U.S. (Newman, Shah \& Collingwood 2018). To counteract this type of antiMexican rhetoric, many politicians have sought to unite themselves with the Latinx population, especially because research has shown that Mexicans in America respond positively to campaigns inviting them to "join the party" - mostly working in favor of the Democratic party (McCann \& Chávez 2016). However, McCann and Chávez (2016) caution that

...immigrants from Mexico who are well resourced and well established in the United States respond to campaign invitations to the same significant degree as those who are less incorporated. This implies that the Mexican-born on the wholeand perhaps the foreign-born population in general - may never be fully and unceasingly integrated into a political party. Such a finding underscores the paramount importance of early childhood political socialization in tying Americans to a reliable party, (McCann \& Chávez 2016: 1207-8).

This research suggests that Mexican-Americans, as well as other immigrants, may be particularly influenced by political campaign strategies, such as the use of code-switching, and that candidates from both parties hoping to gain the vote of immigrants and those of Mexican American ancestry, must continually attempt to curry their favor to align them to their political party.

\section{Methodology}

We relied on a political discourse analysis framework from van Dijk (1997) to guide the data analysis. van Dijk posits that political discourse analysis (PDA) is a systematic account of the relationship between the context and the discursive structures present. In this view, "text and context mutually define each other" (van Dijk 1997: 14). By considering code-switching as a strategic approach to communication, and viewing PDA as context driven, we will gain a clear picture of 
the ways in which Senator Kaine used code-switching in four of his campaign speeches.

Four speeches given by Senator Tim Kaine during the 2016 Presidential campaign were selected for inclusion in this study. These speeches were found on YouTube and selected based on Senator Kaine's use of code-switching. The first speech analyzed was the official announcement of Senator Kaine as Hillary Clinton's running mate, which took place in Miami, Florida on July 23. Also selected was his speech at the Democratic National Convention (DNC) in Philadelphia, Pennsylvania on July 27, where he introduced himself as the Democratic running mate, endorsed Hillary Clinton, and attacked Republican candidate Donald Trump. The other two speeches were from the campaign trail; one took place in Austin, Texas on August 9 and the other was in Lancaster, Pennsylvania on August 30. Both were for the purpose of promoting Hillary Clinton as the next President of the United States.

Each speech was transcribed in its entirety, after which all instances of codeswitching (when he switched from Spanish to English or English to Spanish) were highlighted. Spanish text was translated by a native Spanish speaker, and recorded in a spreadsheet. To determine the purpose for his code-switching, each instance was coded based on common political discourse strategies. That is, his codeswitching was categorized based on the political function it served, and each text could be categorized as serving multiple functions. Thus, coding was not mutually exclusive, and the raters acknowledged that a phrase and/or sentence could have multiple political functions. The data was double-coded by a second trained graduate student to establish inter-rater reliability. Any disagreements on functions were discussed by both coders until a consensus was reached. Due to the qualitative nature of the data and categorization system, we do recognize the inherent subjectivity that may exist in the classification system.

Political discourse strategies were gathered from studies by Chilton (2004), Davletbaeva et al. (2016), Reyes (2015), and van Dijk (1997). Strategies that overlapped between studies and have been found to be common in American political discourse were used in the analysis. These include: a) dissemination of personal information or background-when politicians share the historical background of their families in an effort to erase boundaries between themselves and others; b) repetition-consistent repeating to ingrain sentiments in the listener's minds, to consistently persuade; c) hyperbole-elaborations of their own contributions and "horror stories" about political enemies; d) metaphor-expressing a concept differently than would be expected given the context; e) metonymysubstitutions of an attribute for a moniker, which may be implicit; f) comparisonshighlighting differences between beliefs, characteristics, and attributes of the opposing political party and/or candidate; g) promises for the future-references to actions the candidate will undertake in the future; $h$ ) solidarity-signaling political distinctions through language use to instill group bonding and boundaries; i) legitimization of self as authority-building on personal authority, expressing a 
persona of credibility and expertness; and j) florid verbiage-words and phrases designed to enrich political stances (Chilton 2004; Davletbaeva et al. 2016; Reyes 2015; van Dijk 1997).

\section{Results}

\subsection{Research Question One}

The first research question asked, how did the amount and length of Senator Kaine's use of code-switching vary across the four analyzed speeches? Results show that Senator Kaine used code-switching 25 times across the four speeches, as evidenced by the chunks of his speech that involved a fluid movement between Spanish to English to Spanish or English to Spanish to English. He used codeswitching the most during his speech in Miami, followed by his campaign speech in Austin, Texas (see Figure 1). The context-sensitive nature of code-switching is, of course, expected as there is a higher proportion of Hispanics in Florida and Texas. It should be noted that his code-switching during the speech in Austin consisted of much shorter sentences or phrases, and occurred almost entirely at the beginning of the speech. By contrast, he used code-switching much more frequently throughout the entire Miami speech, and with longer chunks of text; this was also true of his speech at the DNC.

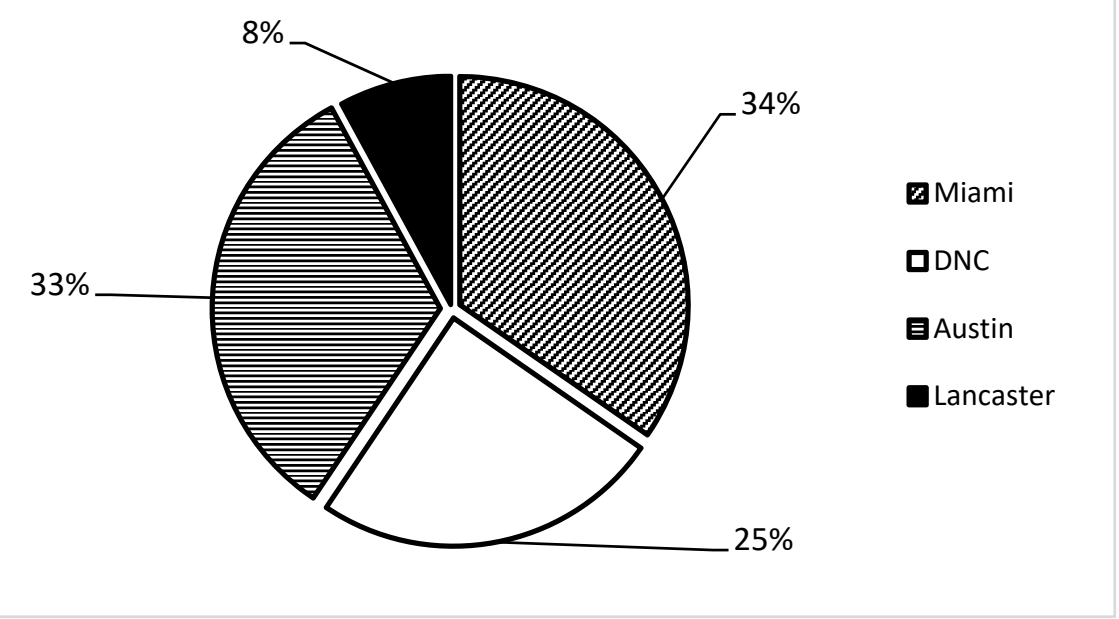

Fig. 1. Code-switching by City

\subsection{Research Question Two}

The second research question asked, how did Senator Kaine use codeswitching as a persuasive rhetorical-discursive device? Analysis showed that Senator Kaine mostly used code-switching to express solidarity (75\%), for repetition (29\%), to disseminate personal information (17\%), to make promises for the future $(17 \%)$, for legitimization (13\%), and to use political metaphors $(13 \%)$. These findings are shown in Figure 2, and will be discussed in further detail in the following sections. 


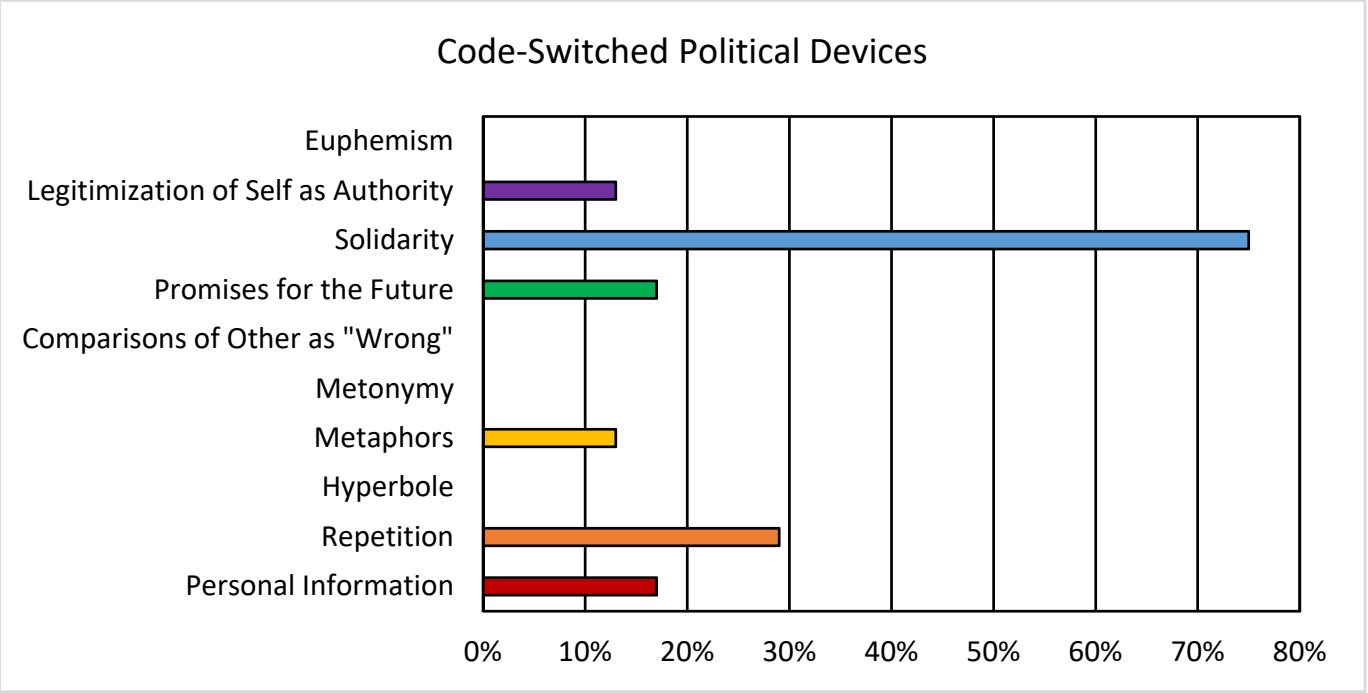

Fig. 2. The Use of Code-switching as a Political Discursive Device

\subsubsection{Code-Switching for Solidarity}

Results of the analysis showed that $75 \%(n=18)$ of Senator Kaine's codeswitching was for the purpose of creating solidarity between himself and his audience. In three of the four speeches reviewed, Senator Kaine used codeswitching to welcome and thank the audience, such as in the following statement from his Miami speech: "Hello Miami...Hello FIU...Bienvenidos a todos. Bienvenidos a todos en nuestro país, verdad, porque somos Americanos todos. I, um, I'm feeling a lot of things today...," (Kaine 2016a). Translated, the Spanish portion means "Welcome to all. Welcome to all in our country, right, because we're all Americans". He also attempted to build solidarity in his Miami and DNC speeches by discussing the time he spent abroad, purposefully switching codes to explain to the audience the values that he learned while living in Honduras, stating "Aprendi los valores de mi pueblo: fe, familia, y trabajo. Faith, family, and work. Los mismos valores de la comunidad latina aqui en nuestro pais, verdad?" (Kaine 2016a; 2016b), which translates to "I learned the values of my people: faith, family, and work. Faith, family, and work. The same values as the Latino community here in our country, right?"

In Miami, Senator Kaine also switched codes (to Spanish) when discussing religion. He established solidarity with the audience when he stated "Soy católico, soy católico. I'm a Catholic and Hillary is a Methodist..." (Kaine 2016a) (Translation: "I'm a Catholic, I'm a Catholic"). In two of his speeches Senator Kaine referred to himself and his running mate, Hillary Clinton, as "compañeros de alma" (Kaine 2016a; 2016b), which translates to "soulmates.

\subsubsection{Code-switching for Repetition}

Repetition is a political strategy that involves restating a word, phrase, or idea to draw attention to and/or to create mental images of its meaning (van Dijk 1997). 
Repetition makes political ideas or concepts more memorable, so that the listener will continue to be persuaded long after the speaking event has concluded (van Dijk 1997). Some political rhetoric includes repetition of campaign catchphrases (such as the "Make America Great Again" slogan made popular by Donald Trump during his 2016 presidential race), however repetition can also be used to simply reiterate political ideas. Senator Kaine engaged in repetition through code-switching during the 2016 election when he discussed his running mate, Hillary Clinton. While in Miami, Austin, and at the DNC he repeatedly stated that she was "lista" (Kaine $2016 a ; 2016 b ; 2016 c)$ or "ready" for the job of President. The use of "lista" is not accidental; during the DNC, Senator Kaine references his time in Honduras, where "lista" was considered to be the highest compliment that could be given. By repeatedly referencing Hillary this way, Senator Kaine was seeking to embed this complimentary image of Hillary in the minds of Latinx voters in a way that he believed they would find meaningful.

\subsubsection{Code-switching to Make Promises for the Future}

Senator Kaine's use of the word "lista" (Kaine 2016a; 2016b; 2016c) was also a promise for the future. Making pledges, assurances, or even threats about future actions or events is a strategy frequently employed by politicians (van Dijk 1997: 27). Senator Kaine's use of the word "lista" promises the American public, and especially Latino voters, that Hillary Clinton will be a great President. By the same token, he used code-switching to make promises that he would prioritize immigration reform during his first 100 days in office.

\subsubsection{Code-switching to Convey Personal Information}

Most political discourse contains personal information about the politician, including family history details, in order to portray the politician as a 'regular person' (Davletbaeva et al. 2016: 244). Senator Kaine used code-switching to share certain personal facts in an effort to identify with his Latinx audience and erase boundaries between himself and them (Davletbaeva et al. 2016). For example, he employed code-switching when discussing his Catholic identity, as many Latinx voters are part of the Catholic faith. Additionally, Senator Kaine used codeswitching when referencing the time he spent in Honduras to convey his experience living in Latinx countries, and his knowledge of the Honduran culture. It is particularly notable that he referenced this during his Miami speech, as Florida has the second largest concentration of Hondurans in the U.S. (Pew Research Center, 2019). Considering that only $24 \%$ of foreign-born Hondurans are U.S. citizens (Pew Research Center, 2019), meaning that the majority are under constant threat of deportation (Medina, 2018), it was particularly important for Senator Kaine to present his personal history, thus emphasizing his group membership, with this population. 
Code-Switching by Senator Tim Kaine

\begin{tabular}{|c|c|}
\hline $\begin{array}{l}\text { Speech Location } \\
\text { \& Date }\end{array}$ & Instances of Code-Switching \\
\hline \multirow[t]{6}{*}{\begin{tabular}{|l|} 
Miami, FL \\
July 23, 2016
\end{tabular}} & $\begin{array}{l}\text { Bienvenidos a todos [welcome to all]. } \\
\text { Bienvenidos a todos en nuestro pais, verdad, porque somos Americanos todos } \\
\text { [Welcome to all in our country, right, because we're all Americans]. I, um...I'm feeling } \\
\text { a lot of things today. Most of all, gratitude. I'm grateful to you Hillary for the trust } \\
\text { that you place in me. And we're going to be compañeros de alma [companions of } \\
\text { the soul/soulmates] in this great lucha [fight] ahead. }\end{array}$ \\
\hline & $\begin{array}{l}\text { And that's why, after racing through the University of Missouri in three years and } \\
\text { starting at Harvard law school, I decided to take a year off from school to volunteer } \\
\text { with Jesuit missionaries in Honduras. ¿Hay un Hondureños, aqui? [Are there any } \\
\text { Hondurans here?] ¿Hay un Hondureños, aqui? [Any Hondurans here?] Okay, un } \\
\text { poquito, si [Okay, a few, yes]. }\end{array}$ \\
\hline & $\begin{array}{l}\text { Aprendí los valores de my pueblo: fe, familia, y trabajo. [I learned the values of my } \\
\text { people: faith, family, and work]. Fe, familia, y trabajo. [Faith, family, and work] ¿Los } \\
\text { mismos valores de la comunidad latina aqui en nuestro pais, verdad? [The same } \\
\text { values as the Latin community here in our country, right?] }\end{array}$ \\
\hline & $\begin{array}{l}\text { Soy Catolico, soy Catolico, [I'm a Catholic, I'm a Catholic] I'm a Catholic and Hilary is } \\
\text { a Methodist but I tell ya, her creed is the same as mine: do all the good you can. }\end{array}$ \\
\hline & $\begin{array}{l}\text { En el senado, assimos eso casi tres años y estamos esperando todavía para la casa } \\
\text { representes a tener un debate un voto en la Sistema de voto de inmigración reform } \\
\text { ¿verdad? Entonces, vamos a trabajar juntos en el primero ciento dios de ese } \\
\text { administracion. [In the Senate, we did that almost three years ago and now we are } \\
\text { still waiting for the House of Representatives to have a debate, a vote on the } \\
\text { immigration reform, right? So we are going to work together on that during the first } \\
100 \text { days of this administration]. }\end{array}$ \\
\hline & $\begin{array}{l}\text { Cualquier persona que llama tanto los estados unidos mereci esta aqui [Anybody who } \\
\text { loves America this much deserves to be here). }\end{array}$ \\
\hline \multirow[t]{3}{*}{\begin{tabular}{|l|l} 
DNC \\
July 27,2016
\end{tabular}} & $\begin{array}{l}\text { That's why I took a year off law school to volunteer with Jesuit missionaries in } \\
\text { Honduras. I taught kids welding and carpentry. Aprendílos valores del pueblo - fe, } \\
\text { familia, y trabajo (I learned the values of my people- faith, family, and work). Faith, } \\
\text { family, and work. Los mismos valores de la comunidad Latina aqui en nuestro país. } \\
\text { Somos Americanos todos [The same values of the Latin community here in our } \\
\text { country. We are all Americans.]. }\end{array}$ \\
\hline & $\begin{array}{l}\text { Hillary Clinton and I are compañeros del alma [companions of the soul/soulmates]. } \\
\text { We share this belief: Do all the good you can. Serve one another. That's what I'm } \\
\text { about. That's what you're about. That's what Bernie Sanders is about. That's what } \\
\text { Joe Biden is about. That's what Barack and Michelle Obama are about. And that's } \\
\text { what Hillary Clinton is about. }\end{array}$ \\
\hline & $\begin{array}{l}\text { The next president will face many challenges. We better elect the candidate who has } \\
\text { proven she can be trusted with the job. The candidate who has proven she's ready } \\
\text { for the job. And, by the way, I use the word "ready" for a specific reason. When I } \\
\text { lived in Honduras, I learned that the best compliment you could give someone was } \\
\text { to say they were "listo" - ready. Not "intelligente" - smart. Not "amable" - } \\
\text { friendly. Not "rico" - rich. But "listo". Because what "listo" means in Spanish is } \\
\text { prepared, battle-tested, rock-solid, up for anything, never backing down. And Hillary } \\
\text { Clinton is "lista". }\end{array}$ \\
\hline
\end{tabular}




\begin{tabular}{|c|c|}
\hline $\begin{array}{l}\text { Speech Location } \\
\text { \& Date }\end{array}$ & Instances of Code-Switching \\
\hline & $\begin{array}{l}\text { Thomas declared all men equal, and Abigail remembered the women. Woodrow } \\
\text { brokered peace, and Eleanor broke down barriers. Jack told us what to ask, and } \\
\text { Lyndon answered the call. Martin had a dream, Cesar y Dolores said si se puede [yes } \\
\text { we can], and Harvey gave his life. Bill bridged a century, and Barack gave us hope. }\end{array}$ \\
\hline \multirow{6}{*}{$\begin{array}{l}\text { Austin, TX } \\
\text { August 9, } 2016\end{array}$} & Hola, ¿que tal? ¿Que tal a todos? [Hi, what's going on? What's going on everybody?] \\
\hline & Mil gracias a Austin. [A million thanks to Austin.] \\
\hline & $\begin{array}{l}\text { I haven't seen Jackie Oreste, who is the state director, Jackie where are you? Give } \\
\text { Jackie a round of applause. Yeah! Um...you got your mayor, I was un alcalde tambien } \\
\text { [A mayor also], in Richmond, VA the state capitol. Mayor is the toughest job there is. } \\
\text { Cuando yo estaba alcalde de Richmond, quince anos, yo encontre este jovencito, Kirk } \\
\text { Watson aqui [When I was the mayor of Richmond, } 15 \text { years, I met this youngster, } \\
\text { Kirk Watson, here] when he was mayor, your state senator and a very dear personal } \\
\text { friend. So glad to be with Kirk. }\end{array}$ \\
\hline & $\begin{array}{l}\text { And then I also understand we have a council member, Pio Altreno aqui, de donde } \\
\text { Pio? Gracias por su trabajo [Pio Altreno, here, where are you Pio? Thank you for your } \\
\text { work]. }\end{array}$ \\
\hline & $\begin{array}{l}\text { When I was in Honduras I was taught this phrase, the highest compliment to pay } \\
\text { somebody was to say that they were "listo" [ready], which is ready, it translates into } \\
\text { ready, but we don't use ready in quite the same way...in Español [Spanish], in } \\
\text { Honduras at least, listo [ready] means prepared, battle tested, rock solid, never } \\
\text { backing down... Hilary Clinton is lista [ready] folks, she's lista, la candidata más lista } \\
\text { de todos [ready, the most prepared candidate of all]. }\end{array}$ \\
\hline & $\begin{array}{l}\text {...and if you want los detalles [the details], the details are important, go to } \\
\text { hilaryclinton.com, you'll get details from Hilary Clinton... }\end{array}$ \\
\hline \multirow[t]{2}{*}{\begin{tabular}{|l} 
Lancaster, PA \\
August 30, 2016
\end{tabular}} & $\begin{array}{l}\text { Mil gracias a ustedes [A million thanks to you guys] ...I am so glad that you pronounce } \\
\text { Lancaster the same way that we do in Virginia. }\end{array}$ \\
\hline & $\begin{array}{l}\text { It's gotta come home and make a difference in the places where people live and } \\
\text { work or no vale la pena [not worth the effort] as they say...it doesn't make any } \\
\text { difference, it's not worth the effort. }\end{array}$ \\
\hline
\end{tabular}

\subsubsection{Code-switching in Metaphors and Legitimization}

Two of the least used political discourse strategies by Senator Kaine were metaphors and legitimization. Metaphors are critical within political discourse (Chilton 2014) because they allow politicians to either mask or highlight certain political situations, ideologies, or mindsets (Davletbaeva et al. 2016). Senator Kaine's description of himself and Hillary Clinton as "compañeros de alma" (Kaine 2016a; 2016b) is an example of a political metaphor. By repeatedly referring to their partnership as such, Kaine illustrates their joint ideologies and mindsets.

By the same token, political metaphors can be used to portray one side as righteous and truthful, and the other as villainous and dishonest (Chilton 2004; van Dijk 1997). This process is called legitimization, and it is articulated through boasts about performance, self-praise, self-justification, self-identification as the authority, and an overall emphasis of one political group as the reasonable and sane choice (Chilton 2004). In several instances, Senator Kaine used code-switching to legitimize himself and the Democratic party. He did this by sharing his background 
as mayor of Virginia and discussing his work on immigration reform in the Senate, which can be seen in Table 1 above.

\section{Discussion}

Political discourse involves conflict resolution and persuasion, with language serving as a primary and significant tool (Hague, Harrop \& Breslin 1998). To aim to influence the minds of recipients is not a straightforward affair for political leaders. It involves the strategic use of some discourse practices that are mostly indirect and implicit. One such strategy is the use of multiple codes (codeswitching) to serve the interests of the agents to achieve a political agenda (van Dijk 2006a). In such cases, the intents are typically concealed from the public. As a result, political speeches, acts, and activities tend to be ideological in nature to fulfill hidden intensions (Fairclough 1995). "Ideology" is assumed as a system of ideas that have social significance, or a set of factual and evaluative beliefs and opinions of a group functioning as a social entity (van Dijk 1998: 48). Using discursive dimensions, political elites intend to change the mind of others for their own interests (van Dijk 1993: 254). The discursive practices pervade through the ideologically employed forms and strategies (Chouliaraki 2005). In this sense, ideology is not only the instrument of domination but also of in-group cohesion, competition, resistance, and opposition wherein status quo and power structures are accepted as legitimate (Wodak 2009). One of the less investigated political discourse strategies used to convey ideology is code-switching.

The first research question asked how did the amount and length of Senator Kaine's use of code-switching vary across the four analyzed speeches? Results showed that Senator Kaine engaged in the most code-switching during his speech in Miami. There are several possible explanations for this, the first of which being that Miami is an international city with a population of roughly 2.6 million, $66.8 \%$ of which is Latinx (U.S. Census 2015). It is likely that Senator Kaine knew that many of the Miami voters would speak Spanish, and thus sought to use his knowledge of Spanish to mark himself as a bilingual politician who identifies with the Latino population of the U.S. and is ready to fight for their needs and interests. For this same reason, Senator Kaine also engaged in code-switching during his Austin, Texas speech. Texas is a border state with a large Latinx population, who encompass about $35 \%$ of the population of the city of Austin (Robinson 2016). A second explanation for Senator Kaine's code-switching during his Miami speech is that it was his first speech as Hillary Clinton's running mate. At this time he wanted to establish himself as a bilingual candidate to gain support from left-wing bilinguals, as well as to differentiate himself from Mike Pence, the Republican vice presidential nominee. Thus, across the four speeches Senator Kaine was using language to perpetuate a particular agenda and ideology that was specific to each area that he visited (Chilton 2004).

The second research question sought to understand how did Senator Kaine use code-switching as a persuasive rhetorical-discursive device? Code-switching is 
routinely adopted by bilinguals to gain the upper hand, which was evidenced through Senator Kaine's strategic choice to use code-switching to gain political favor. Almost half $(46.6 \%)$ of his code-switching was done to create solidarity between himself and his audience, which is likely a response to the 56.6 million Latinx people in the U.S. (U.S. Census 2016) and a recognition that his ability to speak in both Spanish and English is an asset for his campaign.

Code-switching was used to build solidarity substantially more than for any other political discourse strategy. This is not surprising, as it is common for politicians to attempt to establish solidarity between themselves and their audience by explaining their commonalities to the cultural or social group of the audience and through narratives designed to evoke emotions (Reyes 2015). Monolingual politicians often use the plural "we" or possessive "our" to demonstrate solidarity with their audiences (van Dijk 1997). For Senator Kaine, code-switching was strategically employed to create a bond with his audience. He used this strategy early on to increase voter enthusiasm and to establish a level of familiarity with the audience, especially since he was relatively unknown to most Americans before he became Hillary Clinton's running mate. One interesting finding is his use of codeswitching in his welcome statement to the Miami audience; Florida has one of the largest populations of illegal immigrants in the country (Office of Immigration Statistics 2013), so this introductory statement is strategic and fraught with implications. In this case, Senator Kaine spoke in Spanish to show that he supports the immigrants in Miami and that his political party is going to welcome everyone, which is in sharp contrast to the policies of his opponent Donald Trump. Through his strategic use of code-switching the inclusive terms and pronouns 'our country' and 'we all are Americans', and the use of emphatic 'right', Senator Kaine was not only able to convey the goals of the Democratic party, but he was also able to establish intimacy and solidarity with his audience through his use of a language that many feel emotionally connected to.

When Senator Kaine discussed the values he learned while living abroad in Honduras, he was hoping to impress the Latinx community with their shared experiences and his application of Latinx values to his personal and political life. Through this, he hoped to differentiate himself from other political candidates and to gain membership to the Latinx community. By the same token, Senator Kaine engaged in code-switching when discussing his Catholicism. Recent statistics show that 34\% of Catholics are Latinx (Pew Research Center 2015), so his use of codeswitching indicates that he wants the Latino community to recognize that he is 'one of them'. Once again, Senator Kaine highlighted his similarities to the Latinx community using the Spanish code in order to create solidarity. This is similar to how code-switching was used by Nigerian politicians within newspaper ads (Opeibi 2007), indicating that alternating between languages is a strategic and purposeful way for politicians to express solidarity, and one that has long been used by politicians around the world.

Senator Kaine also engaged in repetition through code-switching across the four speeches. For the most part, he was seeking to drive home one important 
political message for his campaign: the Democratic party will welcome immigrants. By saying this in both Spanish and English, Senator Kaine was attempting to make the message accessible to all audience members. He was also seeking to embed the message into the minds of all the Spanish-English bilinguals who were listening, in the hopes that they would recall his words when deciding which party to support. Code-switching and repetition were again combined to highlight that Hillary Clinton was more prepared to be President than her opponent Donald Trump. He used 'lista' to describe Hillary Clinton in a way that could only be understood by the Latinx community. The word 'lista' conveys a shared linguistic experience that could only be understood by members of the same sociocultural circle, and thus its repeated use continually emphasized the alignment of Clinton-Kaine with the Latinx population.

\section{Conclusion}

The findings about Senator Kaine are unique in that there is currently a paucity of research related to code-switching in U.S. political discourse. In order to fully understand these practices, future research is needed on how Senator Kaine's codeswitching was perceived by the public and how it impacted the results of the election. Additionally, it would behoove researchers to determine the ways that bilingual politicians around the world engage in code-switching, what purpose it serves in each context, and how it is received by the different groups of voters. This information could inspire some politicians in the U.S., and other countries, to incorporate code-switching into their discourse practices and could also indirectly promote multilingualism.

Since Senator Kaine was a Spanish-English bilingual speaker, we only analyzed four of his speeches addressing voters with a significant number of Latinx members. It would be insightful to examine other speeches given by Senator Kaine to mostly monolingual white English speakers and compare the findings with the findings of this study. Additionally, this study only examined Senator Kaine's use of code-switching in his Presidential campaign. It is likely that he used codeswitching differently in those speeches than he would in other political scenarios, and thus it is recommended that future researchers examine his use of language in other settings to see how the discourse meets his political agenda.

While building solidarity to gain voters' support through code-switching was a chief concern for Senator Kaine, he also used code-switching to make promises for the future, convey personal information, and express metaphors. Through codeswitching, he sought to indicate that he was speaking directly to the Latinx members of the audience, and was thus highlighting their importance in his campaign. He wanted to illustrate the importance of immigration reform, and assure the Latinx voters that he would not forget his promises once in office. By the same token, he used code-switching to discuss his time spent in Honduras to establish himself as a member of the Latinx community. This aligns with findings by Kementchedjhieva (2016), who determined that the Prime Minister of Bulgaria manipulated his 
language use to appear more like a 'regular guy'. In both examples, the politicians are attempting to use language to establish themselves as members of the community. Finally, Senator Kaine used code-switching to express metaphors about his alignment with the Latinx community, and to make his long history in politics clear to every voter, so that they would consider him a political authority and a supporter of the Latinx population.

(C) Stephanie Moody and Zohreh R. Eslami, 2020
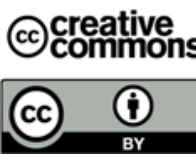

This work is licensed under a Creative Commons Attribution 4.0 International License https://creativecommons.org/licenses/by/4.0/

\section{REFERENCES}

Blom, Jan-Petter, John Gumperz \& Dell Hymes. 1972. Directions in sociolinguistics. $407-434$.

Bwenge, Charles. 2009. Linguistic identity and (re)construction in electoral politics: The case of 2005 Tanzanian parliamentary campaigns. In Koen Bostoen, Akinloye Ojo \& Lioba Moshi (eds.), Selected proceedings of the 39th annual conference on African linguistics, 166-178. Cascadilla Proceedings Project.

Chilton, Paul. 2004. Analysing Political Discourse: Theory and Practice. London, UK: Routledge.

Chouliaraki, Lilie. 2005. Introduction: The soft power of war: Legitimacy and community in Iraq war discourses. Journal of Language and Politics 4(1). 1-10.

Corner, John. 2003. Mediated personal and political culture. Media and the Restyling of Politics. 67-84.

Craig, Geoffrey. 2013. How does a Prime Minister speak?: Kevin Rudd's discourse, habitus, and negotiation of the journalistic and political fields. Journal of Language and Politics 12 (4). 485-507.

Davletbaeva, Diana N., Marianna E. Yashina \& Alina D. Sharafieva. 2016. Linguistic peculiarities of the modern political discourse of Russia and the USA. Journal of Organizational Culture, Communication, and Conflict 20. 242-247.

Fairclough, Norman. 1995. Critical Discourse Analysis. Longman.

Hague, Rod, Martin Harrop \& Shaun Breslin. 1998. Comparative Government and Politics: An Introduction. 4th edn. Palgrave Macmillan.

Hay, Colin. 2013. Political discourse analysis: The dangers of methodological absolutism. Political Studies Review 11 (3). 321-327.

Jarraya, Soufien. 2013. Persuasion in political discourse: Tunisian President Ben Ali's last speech as a Case Study.

Johnson, Kevin R. \& Bernard Trujillo. 2011. Immigration Law and the US-Mexico Border: ¿Si Se Puede?. University of Arizona Press.

Kementchedjhieva, Yova. 2016. Code-switching as strategically employed in political discourse. Lifespans and Styles 2 (1). 3 -9.

Krogstad, Jens Manuel, Jeffrey S. Passel \& D'Vera Cohn. 2019. 5 facts about illegal immigration in the U.S. Pew Research Center. [Electronic resource]. URL: 
https://www.pewresearch.org/fact-tank/2019/06/12/5-facts-about-illegal-immigration-inthe-u-s/

Lipka, Michael. 2015. A closer look at Catholic America. Pew Research Center. [Electronic resource]. URL: http://www.pewresearch.org/fact-tank/2015/09/14/a-closer-look-atcatholic-america/.

McCann, James A., \& Katsuo A. Nishikawa Chavez. 2016. Partisanship by invitation: Immigrants respond to political campaigns. The Journal of Politics 78 (4). 1196-1210.

Medina, Brenda. 2018. Hondurans in South Florida 'hopeless' after Trump administration ends immigration protection TPS. Miami Herald. [Electronic resource]. URL: https://www.miamiherald.com/news/local/article210523599.html

Mirzaei, Azizullah, Zohreh. R. Eslami \& Fatemeh Safari. 2017. Exploring RhetoricalDiscursive Practices of Rouhani's Presidential Campaign and Victory of his Prudenceand-Hope Key: A Discourse of Persuasion. Russian Journal of Linguistics. Special issue Discourse Analysis in the $21^{\text {st }}$ Century: theory and practice 27 (1). 161-182.

Ponton, Douglas, M. 2016. Movements and Meanings towards an Integrated Approach to Political Discourse Analysis. Russian Journal of Linguistics 20 (4). 122-139.

Newman, Benjamin J., Sono Shah \& Loren Collingwood. 2018. Race, place, and building a base: Latino population growth and the nascent Trump campaign for president. Public Opinion Quarterly 82 (1). 122-134.

Noe-Bustamante, Luis, Antonio Flores \& Sono Shah. 2019. Facts on Latinxs of Honduran origin in the United States, 2017. Pew Research Center. [Electronic resource]. URL: https://www.pewresearch.org/Latinx/fact-sheet/u-s-Latinxs-facts-on-honduran-originlatinos/.

Obeng, Samuel Gyasi. 1997. Language and politics: Indirectness in political discourse. Discourse \& Society 8 (1). 49-83.

Opeibi, Tunde Olusola. 2007. One message, many tongues: An exploration of media multilingualism in Nigerian political discourse. Journal of Language and Politics 6 (2). $223-248$.

Quam, Justin \& Marianna Ryshina-Pankova. 2016. "Let me tell you...” Audience Engagement Strategies in the Campaign Speeches of Trump Clinton, and Sanders. Russian Journal of Linguistics 20 (4). 140-160.

Reyes, Antonio. 2015. Building intimacy through linguistic choices, text structure, and voices in political discourse. Language \& Communication 43. 58-71.

Robinson, R. 2016. Top ten demographic trends in Austin, Texas. Austintexas.gov

Saldaña, Johnny. 2015. The Coding Manual for Qualitative Researchers. Sage Publishing.

Scotton, Carol Myers \& William Ury. 1977. Bilingual strategies: The social functions of codeswitching. International Journal of the Sociology of Language 13. 5-20.

Uzum, Baburhan \& Melike Uzum. 2010. The historical and linguistic analysis of Turkish politician's' speech. International Journal of Politics, Culture, and Society 23 (4). $213-224$.

van Dijk, Teun A. 2006a. Discourse and manipulation. Discourse \& Society 17 (2). 359-383.

van Dijk, Teun A. 2006b. Politics, ideology, and discourse. Encyclopedia of Language \& Linguistics. [Electronic resource]. URL: https://doi.org/10.1016/b0-08-044854-2/00722-7 van Dijk, Teun A. 1998. Ideology: A Multidisciplinary Approach. SAGE.

van Dijk, Teun A. 1997. What is political discourse analysis? Belgian Journal of Linguistics 11 (1). $11-52$.

van Dijk, Teun A. 1993. Principles of critical discourse analysis. Discourse \& Society 4 (2). 249-283.

Wei, Jennifer M.Y. 2003. Codeswitching in campaigning discourse: The case of Taiwanese president Chen Shui-bian. Language and Linguistics 4 (1). 139-165. 
Weiss, Gilbert, \& Ruth Wodak. 2003. Introduction: Theory, interdisciplinarity and critical discourse analysis. In Gilbert Weiss \& Ruth Wodak (eds.), Critical Discourse Analysis: Theory and Interdisciplinarity, 1-34. Hampshire: Palgrave MacMillan.

Wodak, Ruth. 2009. Language and politics. In Jonathan Culpeper, Paul Kerswill, Ruth Wodak, Tony McEnery \& Francis Katamba (eds.), English Language: Description, Variation and Context, 576-593. Palgrave Macmillan.

Wodak, Ruth. 2004. Preface: The power of language in political discourse. Journal of Language and Politics 3 (3). 381-383.

Young, Vershawn Ashanti. 2009. "Nah, we straight": An argument against code switching. $J A C .49-76$.

\section{Internet Resources}

ABC15 Arizona. 2016, July 27. Full Tim Kaine acceptance speech 2016 Democratic National Convention. YouTube. https://youtu.be/w1 scCwsnwIs

Grossmand, Les. 2016, July 23. Tim Kaine full speech in English and Spanish in Miami. YouTube. https://youtu.be/rR0j7Xt8ez4

Grossmand, Les. 2016, July 23. Tim Kaine full speech in English and Spanish in Miami. YouTube. https://youtu.be/rR0j7Xt8ez4

Kaine, Tim. 2016, August 9. Full speech: Tim Kaine speech in Austin, Texas. YouTube. https://youtu.be/LfMltcKO43c

Kaine, Tim. 2016, August 30. Tim Kaine speech in Lancaster, PA. YouTube. https://youtu.be/hfdyYTlhogs

Office of Immigration Statistics. 2013. Immigration data and statistics. Department of Homeland Security. https://www.dhs.gov/data-statistics

U. S. Census Bureau. 2015. Quick facts: Miami-Dade County, Florida. http://www.census.gov/ quickfacts/table/RHI725215/12086

U. S. Census Bureau. 2016. Newsroom: Facts for features. http://www.census.gov/ newsroom/facts-for-features/2016/cb16-ff16.html

\section{Article history:}

Received: 26 February 2020

Revised: 18 March 2020

Accepted: 15 March 2020

\section{История статьи:}

Дата поступления в редакцию: 26 февраля 2020

Дата принятия к печати: 15 марта 2020

\section{Bionotes:}

STEPHANIE MOODY has over a decade of experience teaching elementary ESL, and is currently a Ph.D. candidate at Texas A\&M University. Her research focuses on translanguaging as a literacy strategy and pre-service teacher preparation for ELL writing instruction.

\section{Contact information:}

Texas A\&M University

College Station, Texas, USA

e-mail: smmoody@tamu.edu

Orcid: 0000-0001-7796-130X 
ZOHREH R. ESLAMI is a Professor in Bilingual/ESL Education program in the Department of Educational Psychology at Texas A\&M University. She has published more than 120 journal articles in journals such as Intercultural pragmatics, ELT Journal, Modern Language Journal, System, Journal of Pragmatics, Journal of Asian Pacific Communication, and Bilingual Education Journal. Her research interests include intercultural communication, Discourse Analysis, Instructional and intercultural pragmatics, cyber-pragmatics, L2 literacy development, L2 literacy in content areas, and task-based language teaching and technology.

\section{Contact information:}

Texas A\&M University

College Station, Texas, USA

Texas A\&M University-Qatar

Doha, Qatar

e-mail: zeslami@tamu.edu

ORCID: 0000-0003-2969-5056

\section{Сведения об авторах:}

СТЕФАНИ МУДИ имеет более чем десятилетний опыт преподавания английского языка как иностранного. В настоящее время она работает над диссертацией в Техасском университете A\&M. Область ее исследования включает переключение кода, подготовку преподавателя к работе по программе ELL.

\section{Контактная информация:}

Texas A\&M University

College Station, Texas, USA

e-mail: smmoody@tamu.edu

ORCID: 0000-0001-7796-130X

ЗОХРЭ Р. ЭСЛАМИ - профессор кафедры педагогической психологии в Техасском университете A\&M, США. Реализует программу двуязычного образования / преподавания английского языка как иностранного языка. Она автор более 120 статей в таких журналах, как Intercultural pragmatics, System, ELT Journal, Modern Language Journal, Journal of Pragmatics, Journal of Asian Pacific Communication, Bilingual Education Journal. Область ее исследований - межкультурная коммуникация, дискурс-анализ, учебная и межкультурная прагматика, кибер-прагматика, развитие грамотности в обучении иностранному языку, применение технологий в обучении иностранному языку.

\section{Контактная информация:}

Texas A\&M University

College Station, Texas, USA;

Texas A\&M University-Qatar

Doha, Qatar

e-mail: zeslami@tamu.edu

ORCID: 0000-0003-2969-5056 